\title{
Pathological Role of Peptidyl-Prolyl Isomerase Pin1 in the Disruption of Synaptic Plasticity in Alzheimer's Disease
}

\author{
Lingyan Xu, ${ }^{1}$ Zhiyun Ren, ${ }^{1}$ Frances E. Chow, ${ }^{2}$ Richard Tsai, ${ }^{2}$ \\ Tongzheng Liu, ${ }^{3}$ Flavio Rizzolio, ${ }^{4,5}$ Silvia Boffo, ${ }^{4,5}$ Yungen $\mathrm{Xu},{ }^{6}$ \\ Shaohui Huang, ${ }^{7}$ Carol F. Lippa, ${ }^{2}$ and Yuesong Gong ${ }^{1,2}$ \\ ${ }^{1}$ Jiangsu Key Laboratory for Functional Substance of Chinese Medicine, Department of Biopharmaceutics and Food Science, \\ School of Pharmacy, Nanjing University of Chinese Medicine, Nanjing 210023, China \\ ${ }^{2}$ Department of Neurology, Drexel University College of Medicine, Philadelphia, PA 19102, USA \\ ${ }^{3}$ Department of Oncology, Mayo Clinic, Rochester, MN 55905, USA \\ ${ }^{4}$ Sbarro Institute for Cancer Research and Molecular Medicine, Center for Biotechnology, Temple University, Philadelphia, \\ PA 19122, USA \\ ${ }^{5}$ Department of Molecular Science and Nanosystems, Ca' Foscari Università di Venezia, Via Torino 155, 30172 Venezia-Mestre, Italy \\ ${ }^{6}$ Department of Medicinal Chemistry, China Pharmaceutical University, Nanjing 21009, China \\ ${ }^{7}$ Department of Physiology, University of Pennsylvania School of Medicine, Philadelphia, PA 19104, USA
}

Correspondence should be addressed to Carol F. Lippa; carol.lippa@drexelmed.edu and Yuesong Gong; ygong@njucm.edu.cn

Received 28 October 2016; Accepted 12 December 2016; Published 26 March 2017

Academic Editor: Jason Huang

Copyright (C) 2017 Lingyan Xu et al. This is an open access article distributed under the Creative Commons Attribution License, which permits unrestricted use, distribution, and reproduction in any medium, provided the original work is properly cited.

\begin{abstract}
Synaptic loss is the structural basis for memory impairment in Alzheimer's disease (AD). While the underlying pathological mechanism remains elusive, it is known that misfolded proteins accumulate as $\beta$-amyloid $(\mathrm{A} \beta)$ plaques and hyperphosphorylated Tau tangles decades before the onset of clinical disease. The loss of Pinl facilitates the formation of these misfolded proteins in AD. Pinl protein controls cell-cycle progression and determines the fate of proteins by the ubiquitin proteasome system. The activity of the ubiquitin proteasome system directly affects the functional and structural plasticity of the synapse. We localized Pinl to dendritic rafts and postsynaptic density (PSD) and found the pathological loss of Pin1 within the synapses of AD brain cortical tissues. The loss of Pin1 activity may alter the ubiquitin-regulated modification of PSD proteins and decrease levels of Shank protein, resulting in aberrant synaptic structure. The loss of Pinl activity, induced by oxidative stress, may also render neurons more susceptible to the toxicity of oligomers of $A \beta$ and to excitation, thereby inhibiting NMDA receptor-mediated synaptic plasticity and exacerbating NMDA receptor-mediated synaptic degeneration. These results suggest that loss of Pinl activity could lead to the loss of synaptic plasticity in the development of $\mathrm{AD}$.
\end{abstract}

\section{Introduction}

The hallmark pathological lesions of Alzheimer's disease $(\mathrm{AD})$ are $\beta$-amyloid $(\mathrm{A} \beta)$ plaques, neurofibrillary tangles, and synaptic loss [1]. Among these, $\mathrm{A} \beta$ plaques and tangles can be detected decades before AD symptoms arise [2-4]. Synaptic loss begins in preclinical AD and is the strongest anatomical correlate of the degree of clinical impairment [5]. The molecular pathophysiology of synaptic dysfunction remains elusive, particularly the molecular events that lead up to the loss of synaptic plasticity decades before the onset of clinical disease [6].

Oligomers of $\mathrm{A} \beta$, the early aggregates of $\mathrm{A} \beta$ peptides, have been suggested as culprits in dysfunction of synaptic plasticity in early $\mathrm{AD}$ patient brains [1]. Pinl is a unique peptidyl-prolyl isomerase that catalyzes cis-trans isomerization of phosphorylated Ser/Thr-Pro motifs. Increase in oligomers of $\mathrm{A} \beta$ and other age-related insults induce oxidative stress [7], which could cause the loss of Pinl activity [8, 9]. Interestingly, loss of Pinl facilitates formation of plaques 
and tangles [10-12], suppresses neuronal differentiation [13], and induces neurodegeneration [14]. The early aggregates of plaques and tangles associate with detergent-resistant rafts and with the postsynaptic density (PSD) $[15,16]$ which is crucial in organizing glutamate receptors within dendritic rafts. Activation of an NMDA receptor can induce the phosphorylation of several hundred PSD proteins [17]. This includes hundreds of Ser/Thr-Pro motifs [18], a set of which upon cis-trans isomerization by Pinl may affect ubiquitin modification of proteins $[19,20]$. The activity of the ubiquitin proteasome system (UPS) can directly alter the plasticity of the PSD [21, 22]. PSD proteins are organized by Shank proteins $[23,24]$. Mutation of Shank3 leads to modification of ubiquitin in Shank3 protein and results in loss of glutamate receptors within an aberrant PSD structure [25-27]. Shank3 protein is lost and highly modified by ubiquitin in synapses of AD patient brains $[28,29]$. Pinl controls protein synthesis in dendritic spines [30]. These findings indicate that loss of Pin1 activity could directly affect synaptic plasticity in the brains of $\mathrm{AD}$ patients.

We localized Pinl to dendritic rafts and to the PSD and found a pathological loss of Pin1 within the synapses of $\mathrm{AD}$ patient brains. Loss of Pinl activity may increase the modification of ubiquitin in PSD proteins and lead to the loss of Shank protein, resulting in aberrant PSD structure. This renders the synapse more susceptible to the toxic assault of oligomers of $A \beta$ and excitation, thereby inhibiting synaptic plasticity and inducing synaptic degeneration, which may accelerate synaptic loss in preclinical AD. These findings could distinguish Pin1 as a target with the potential to protect synaptic function in preclinical AD.

\section{Results}

2.1. Pin1, Phosphorylated Tau, Oligomers of $A \beta$, and Glutamate Receptor Coincidently Exist in Detergent-Resistant Dendritic Rafts and PSD Fractions. To detect Pin1 proteins in detergent-resistant dendritic rafts and PSD, synaptosome fractions were effectively isolated from the frontal cortical tissues of human $\mathrm{AD}$ and normal control brains, and the synaptic markers PSD95 and Shank3 were enriched up to 9 and 8 times in synaptosome fractions, respectively (Figure 1(b)). The synaptosomes were further treated to isolate dendritic rafts and PSDs, and dendritic rafts and PSDs were analyzed by Western blot or dot blot.

First, to analyze the dendritic rafts, flotillin and GM1 ganglioside were used as markers. Both raft markers were detected in fraction 4 of the sucrose gradient. Calnexin, an ER marker used as a negative marker, was not detected in fraction 4. Pin1, NR1, and Shank3 coincidently were found in fraction 4 of the sucrose gradient from cortical tissues of human control and AD brains (Figure 1(a)). Meanwhile, phosphorylated Tau and oligomers of $\mathrm{A} \beta$ were detected obviously in dendritic rafts isolated from cortical tissues of human $\mathrm{AD}$ brains, but much less from cortical tissues of control brains (Figure 1(a)).

Second, to analyze PSD, PSD95 and Shank3 were used as markers of PSD. The PSD1 fraction was comprised of pellets of synaptosomes that were treated once by Triton X-100, and the PSD2 fraction was comprised of pellets of PSD1 treated by Triton X-100 one additional time [31] (Figure 1(b)). We found Pinl proteins in the synaptosome and in the PSD fractions from cortical tissues of $\mathrm{AD}$ and control brains. Pinl proteins exist in PSD fraction coincidently containing: PSD95, Shank3, and NR1. However, oligomers of $\mathrm{A} \beta$ and hyperphosphorylated Tau were observed only in PSD fractions of AD brain cortical tissues and not in PSD of control cortical tissues (Figure 1(b)). Although Pinl proteins were not enriched in synaptosome and PSD fractions, these results suggest that Pinl exist in dendritic rafts and in PSD.

Third, to further clarify the location of Pinl at the synapse, the cultured cortical neurons of C57/BL6 mice at 21 DIV were used to detect the distribution of Pin1, Shank3, and NR1 proteins by immunocytochemical analysis. Shank3 proteins are expressed at the PSD in the dendritic spine of excitatory neurons [23]. We found that Pin1 proteins also partly colocalized with NR1 proteins along with Shank3 proteins at the dendritic spines of excitatory neurons (Figure 2).

2.2. Pin1 Proteins Are Altered at Synapses of Human AD and Tg2576 AD Mice Brains. Pinl proteins have been identified at detergent-resistant synaptic structures: dendritic rafts and PSD (Figures 1 and 2). The loss of Pinl is involved in the formation of $\mathrm{A} \beta$ plaques and hyperphosphorylated Tau tangles in $\mathrm{AD}$ patient brains $[10,11]$. To detect whether Pinl proteins were involved in the pathological changes found in synapses of $\mathrm{AD}$ patient brains, the cortical frontal tissues of human $\mathrm{AD}$ and age-matched control brains were used to isolate synaptosomes (Figure 1(b)). Synaptosomes were fractioned in $0.5 \%$ Triton X-100 by ultracentrifuge into a soluble synaptic fraction, synaptic rafts fraction, and PSD fraction. The Pin1 proteins in these fractions were separated by $16.5 \%$ Tristricine gel and the levels of these Pinl proteins were detected by Western blot. We found total synaptic Pin1 protein to be significantly lost by $39 \%$ in human AD patient frontal cortical tissues compared with that in control tissues. The soluble synaptic Pinl proteins were also significantly decreased by $76 \%$ in these $\mathrm{AD}$ samples, and the detergent-resistant Pin1 was significantly increased in dendritic rafts but significantly decreased in PSD fractions from cortical tissues of AD patient brains (Figure 3(a)). To confirm these pathological changes, the experiment was repeated with cortical tissues isolated from cortical tissues of $\operatorname{Tg} 2576$ amyloid-AD model mice brains at 18 months, which are equivalent to 55 years in human [32]. The total synaptic Pinl protein and soluble synaptic Pinl protein also showed significant loss, and the levels of Pin1 protein at dendritic rafts showed significant increase in Tg2576 mice brains (Figure 3(b)). These results indicate that the pathological loss of Pinl proteins at the synapse could be involved in synaptic dysfunction in AD development.

2.3. Blocking of Pin1 Activity Increases the Modification of Ubiquitin in PSD Proteins. The activity of Pinl protein affects ubiquitin modification of proteins [20], and the activity of the UPS can directly alter the plasticity of the PSD [21, 22]. The loss of Pinl could alter the modification of ubiquitin in PSD proteins, leading to the alteration of structural and functional 


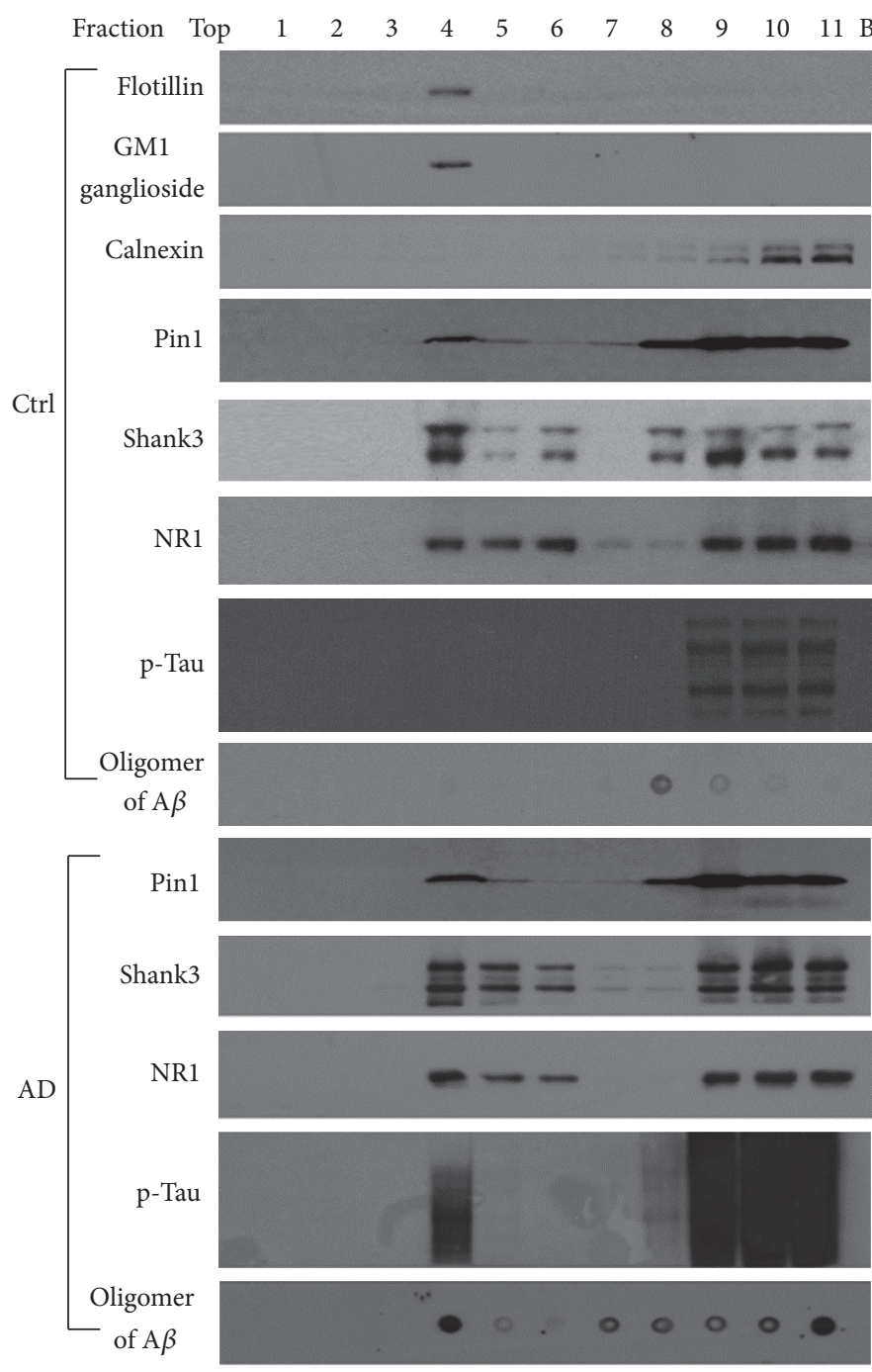

(a)

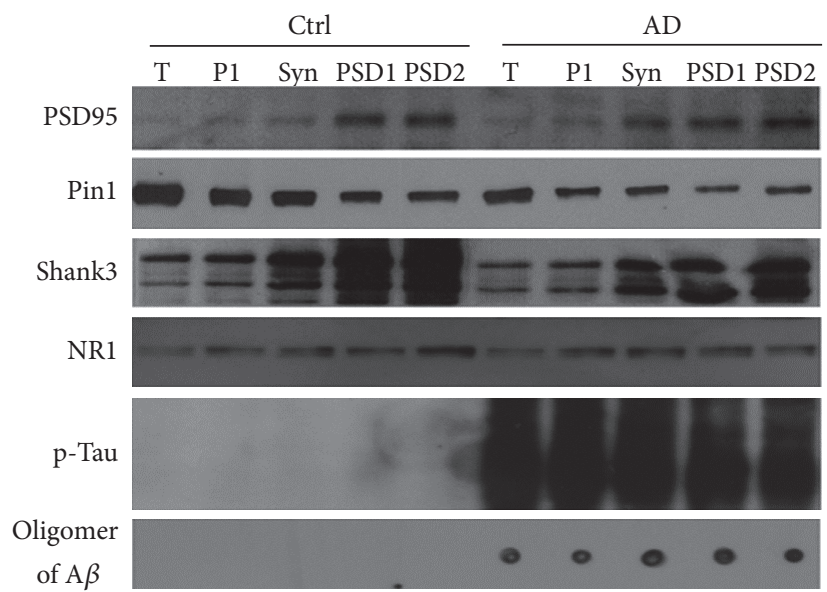

(b)

FIGURE 1: Pinl proteins exist in detergent-resistant dendritic rafts and PSD fractions coincidently containing phosphorylated Tau, oligomers of $\mathrm{A} \beta$, and glutamate receptor. The detergent-resistant synaptosome suspension was fractionated by sucrose gradient ultracentrifugation to isolate dendritic rafts and PSDs. (a) Analysis of dendritic rafts. Proteins in ultracentrifuged fractions at equal volume were analyzed by Western blot or dot blot. Fraction 4 contained flotillin and GM1 ganglioside, known markers for rafts, along with Pinl, p-Tau, oligomers of A $\beta$, Shank3, and NR1 proteins. Fraction 4 did not show calnexin, a marker of endoplasmic reticulum (ER). (b) Analysis of the PSD. PSD proteins at equal amounts were analyzed by Western blot or dot blot. PSD95 and Shank3, both known protein markers of the PSD, were enriched in the PSD fraction (PSD2), along with Pin1, NR1, p-Tau, and oligomers of A $\beta$. Ctrl: human control tissues; AD: human AD tissues; T: total tissue; P1: total membrane; NR1: a subunit of NMDA receptor; Syn: synaptosome; PSD1: pellets from the synaptosome treated once by $0.5 \%$ Triton X-100; PSD2: pellets from PSD1 treated once more by $0.5 \%$ Triton X-100. 

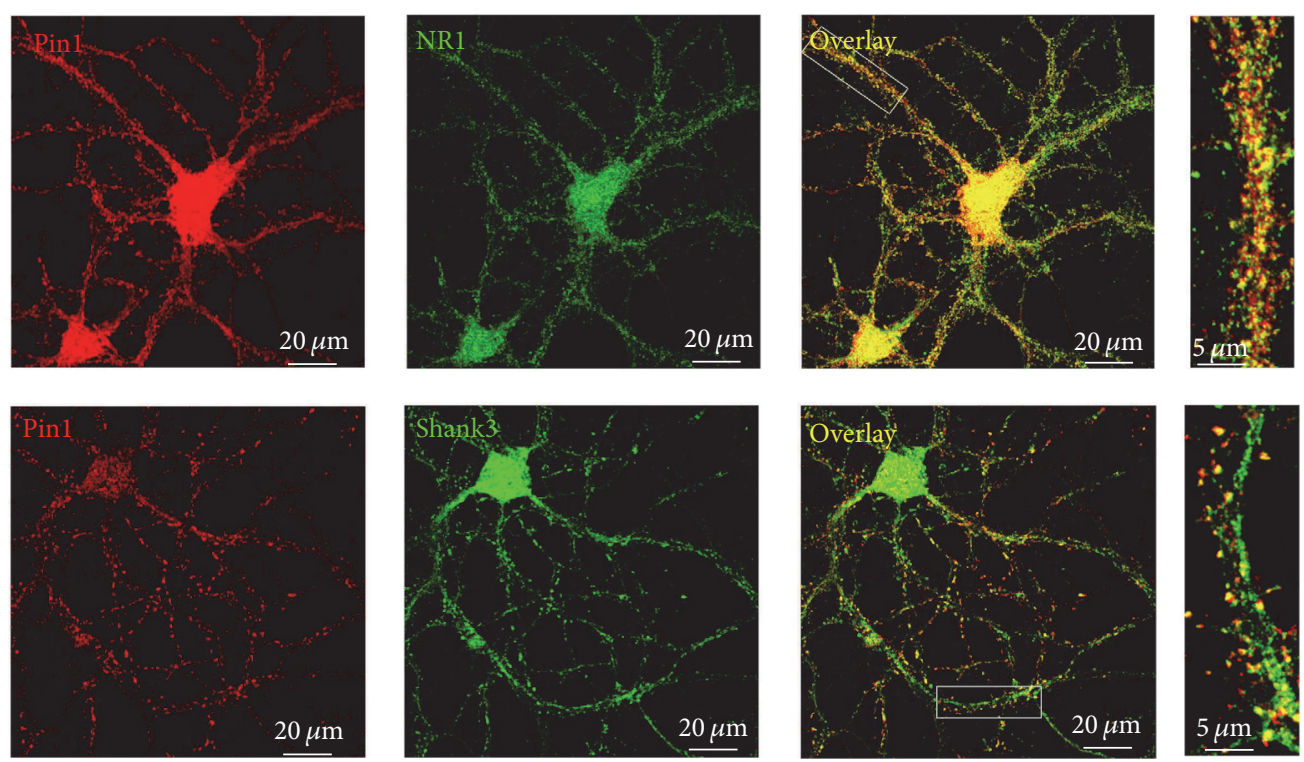

FIgURE 2: Pin1 proteins are partly colocalized with Shank3 and NR1 proteins at dendritic spines of neurons. Cortical neurons at 21 DIV were double immunolabeled for Pin1 (red) and Shank3 (green) or NR1 (green). When the images were merged, the yellow in the overlay showed colocalization of Pinl-immunoreactive puncta with Shank3 and NR1 proteins. Right panels were high-magnification images of selected overlays.

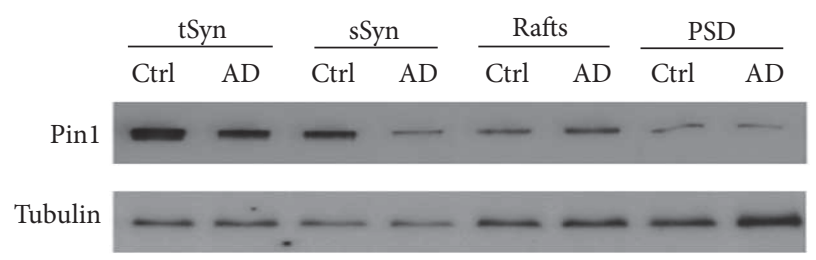

(a)

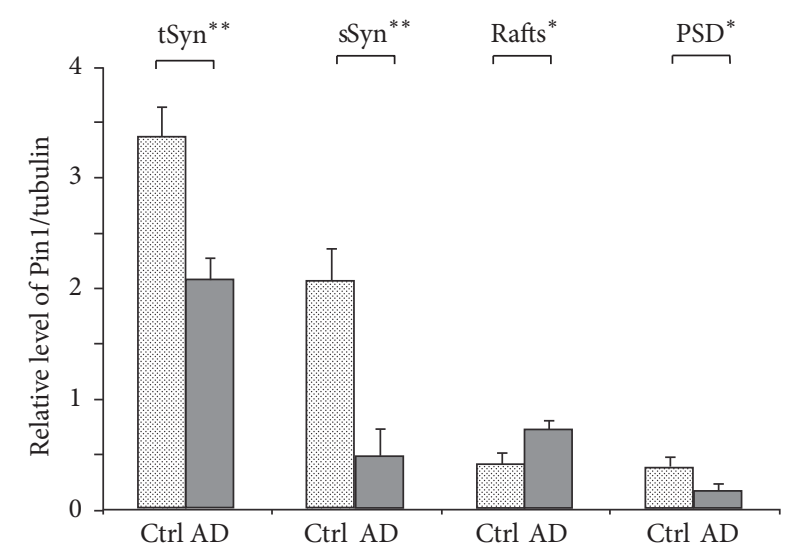

(b)

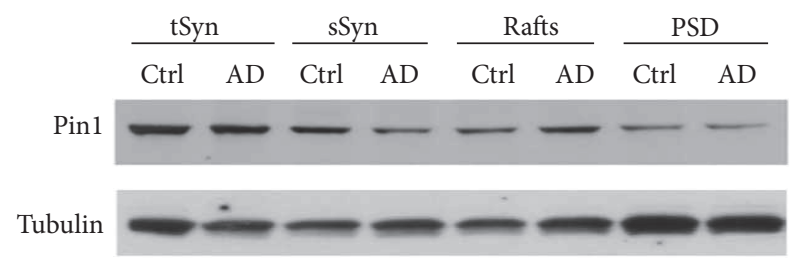

(c)

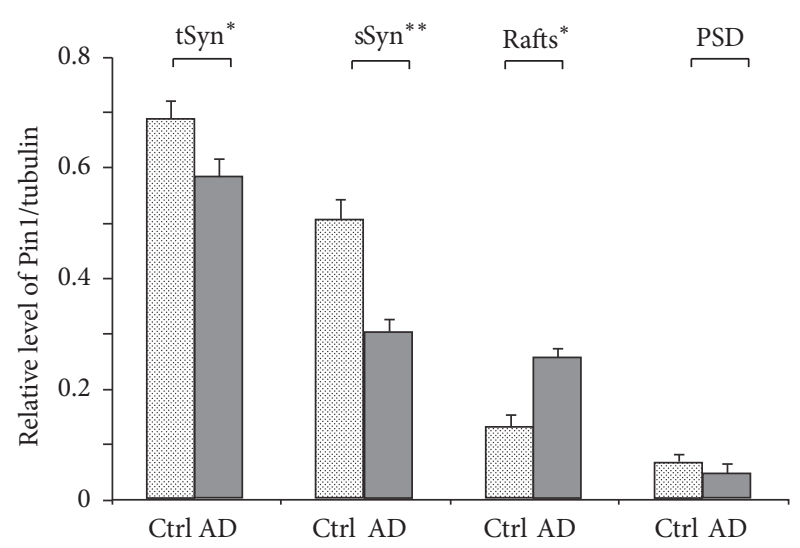

(d)

FIgURE 3: Pinl proteins show pathological loss in the synapses of human AD and Tg2576 AD model mice. The Pinl proteins in synaptosomes, soluble synaptosomes, dendritic rafts, and PSD fractions were isolated from human frontal cortical tissues (a and b) and from Tg2576 AD model mice cortical tissues ( $c$ and d) and were detected by Western blot. (a and c) Representative Western blot experiment. (b and d) Results from densitometric imaging of these same samples (human $\mathrm{AD}$ frontal cortical tissues, $n=8$; human frontal cortical tissues, $n=5$; Tg2576 mice, $n=7$; and wild-type mice, $\left.n=7 ;{ }^{*} p<0.05,{ }^{* *} p<0.01\right)$. Ctrl: human control frontal cortical tissues; AD: human AD frontal cortical tissues; tSyn: the supernatant of synaptosomes extracted by $1 \%$ SDS; sSyn: the supernatant of synaptosomes extracted by $0.5 \%$ Triton X-100. 


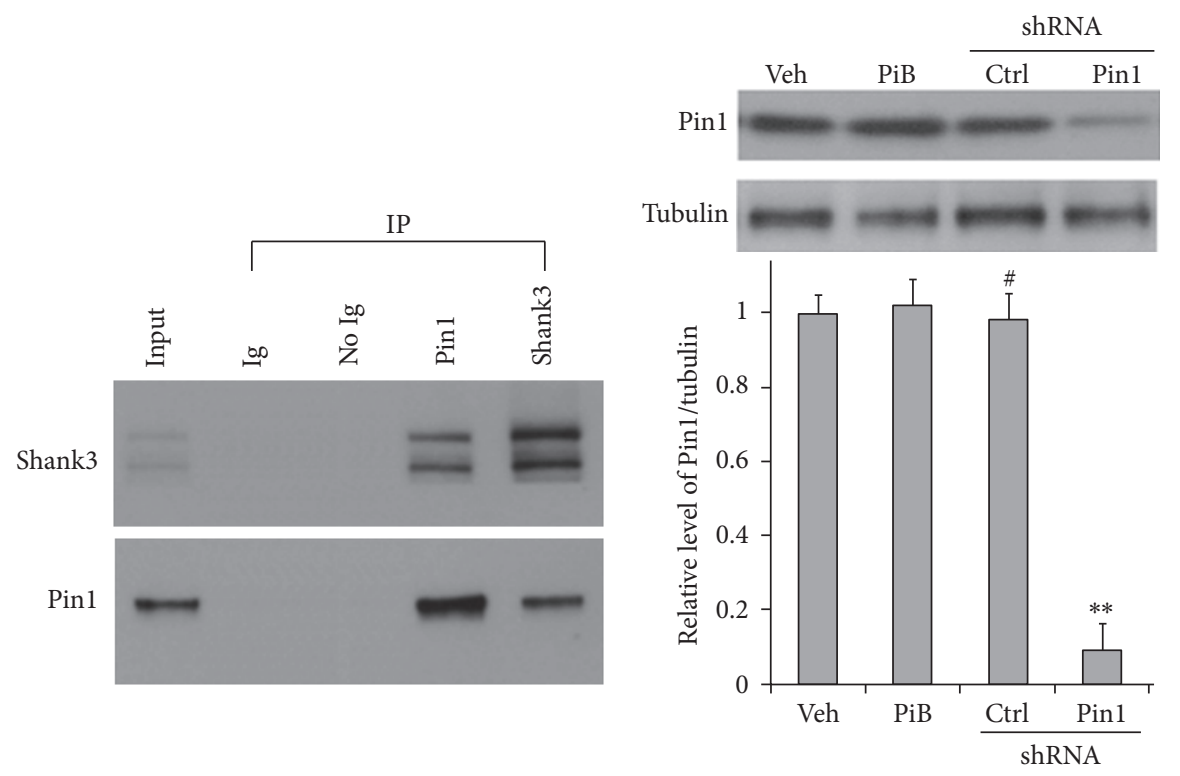

(a)

(b)

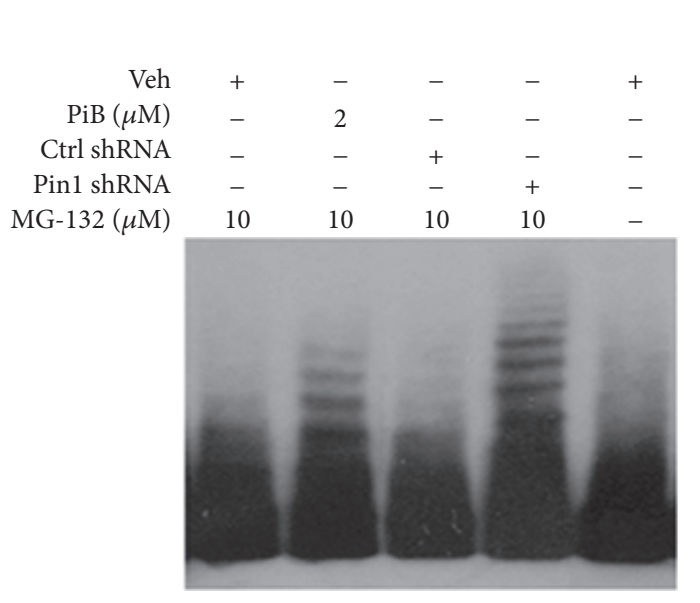

(c)

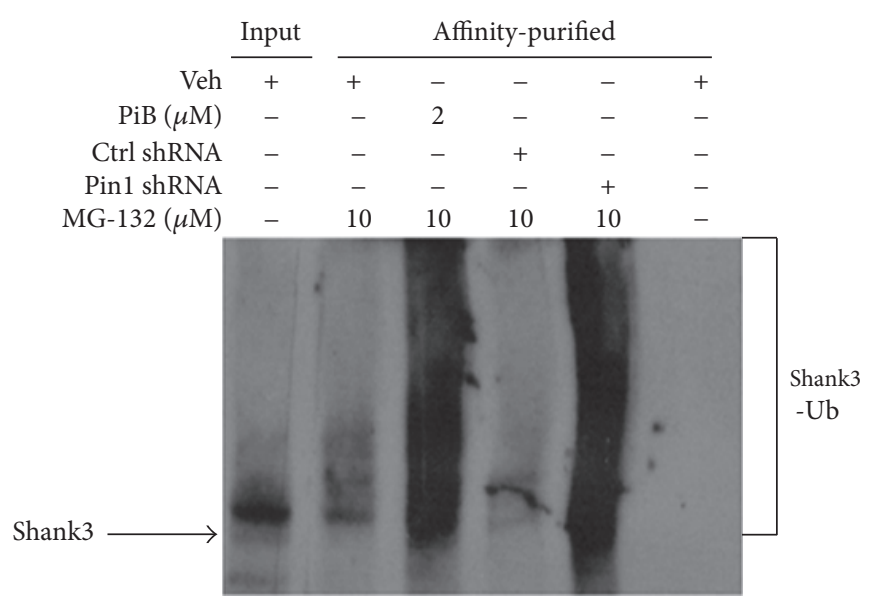

(d)

FIGURE 4: Blocking of Pinl activity increases the modification of ubiquitin in PSD proteins. C57/BL6 cortical neurons at 21 DIV were incubated with PiB and MG-132 for $24 \mathrm{~h}$ and transfected by Pinl shRNA or control shRNA lentivirus for $48 \mathrm{~h}$, respectively; the PSDs were isolated and analyzed with Western blot. (a) Coimmunoprecipitation between Pinl and Shank3 proteins. (b) Total Pinl proteins were knocked down $(n=7$ dishes for each experimental condition, ${ }^{* *} p<0.01 ;{ }^{\#} p>0.05$ ). (c) Ladders of Shank3 proteins after the loss of Pin1 activity. (d) Ubiquitinated Shank3 proteins were enriched by ubiquitin-affinity purification and recognized by Shank3 antibody in Western blot.

plasticity of the PSD. To test this hypothesis, cultured cortical neurons of C57/BL6 mice at 21 DIV were incubated with $\mathrm{PiB}$, the selective inhibitor of Pinl $[33,34]$, and MG-132, a proteasome inhibitor, for $24 \mathrm{~h}$ at different concentrations (Figure 4(a)). The neurons were collected and PSD fractions were isolated. PSD proteins at equal amounts were analyzed by Western blot. The ubiquitin-labeled PSD proteins were detected by anti-ubiquitin antibodies. Ubiquitin-labeled PSD proteins significantly increased after the cultured neurons were incubated with $\mathrm{PiB}$ for $24 \mathrm{~h}$ (Figures $4(\mathrm{c})$ and $4(\mathrm{~d})$ ). Because Shank3 protein is a core protein of PSD [23] and Shank3 protein shows polyubiquitination and loss in $\mathrm{AD}[28$, 29], Shank3 protein was analyzed in this test. We observed Pinl protein and Shank3 protein in synaptosome from cortical tissues of human control brains showed associated together by immunoprecipitation (Figure 4(a)). Meanwhile, Pinl shRNA was used to knock down Pinl protein in cultured neurons; the level of Pinl protein was decreased by about $82 \%$ after neurons were transfected by Pinl shRNA lentivirus for $48 \mathrm{~h}$ (Figure $4(\mathrm{~b})$ ). We used these test conditions to treat cultured neurons with $\mathrm{PiB}$ for $24 \mathrm{~h}$ and with Pinl shRNA for $48 \mathrm{~h}$. The PSD fractions were then isolated. When the amount of PSD protein was increased to $75 \mu \mathrm{g}$ for Shank3 Western blot, ladders of Shank3 proteins were apparent in the PSD fractions after treatment with Pinl inhibitor PiB or Pinl shRNA (Figure 4(c)). To confirm that these ladders of Shank3 proteins contained ubiquitin modification, we enriched the ubiquitinated proteins in isolated PSD using a 
polyubiquitin enrichment kit. These ubiquitinated proteins were recognized by Shank3 antibody in Western blot, and Shank3 showed obvious ubiquitination (Figure 4(d)). These results indicate that loss of Pinl activity may lead to an increase in ubiquitinated proteins in the PSD, which could increase the degradation of Shank 3 and other PSD proteins $[28,29]$, leading to changes in the structure of the PSD in AD development.

2.4. Blocking of Pin1 Activity Disrupts the Structural Plasticity of PSD. Thousands of proteins interact together at the PSD. Shank proteins organize these proteins to form macromolecules including NMDA, AMPA, and mGlu receptors [23]. Because of Shank proteins' large organizational role, the loss of Shank3 proteins and the extensive modification of ubiquitin in Shank3 proteins may result in aberrant PSD structure and glutamate receptor loss [26, 27]. Shank3 proteins show loss and are highly modified by ubiquitin in $\mathrm{AD}$ $[28,29]$. To evaluate the pathological degradation of PSD proteins after loss of Pin1 activity in AD brain, we selected Shank3 as the functional and structural marker of changes in PSD. The mature synapses at 21 DIV are more sensitive to NMDA and other insults. Cultured neurons of C57/BL6 mice at 21 DIV were treated by $\mathrm{PiB}$ at $0.5 \mu \mathrm{M}$ and $2.0 \mu \mathrm{M}$ to block Pin1 activity and with control vehicle for $24 \mathrm{~h}$ (Figures 5(a)-5(f)), while cultured $\mathrm{Pinl}^{+/+}, \mathrm{Pinl}^{+/-}$, and $\mathrm{Pinl}^{-/-}$neurons at 21 DIV were also examined (Figures 5(g)-5(l)). The neurons on coverslips were analyzed using immunocytochemistry to detect Shank3 protein levels, and the neurons in dishes were used to isolate PSD fractions, which were analyzed by Western blot. We found that C57/BL6 neurons treated with $\mathrm{PiB}$ showed significant reduction in Shank3 protein levels (Figures 5(a)-5(f), 5(m), and 5(n)). These results indicated that the loss of Pin1 activity could lead to the loss of Shank3 protein and thus affect the structure of the PSD. The same results were replicated in cultured $\mathrm{Pinl}^{-/-}$neurons, but not in $\mathrm{Pinl}^{+/+}$or Pin1 ${ }^{+/-}$neurons at $21 \mathrm{DIV}$ (Figures 5(g)-5(l), $5(\mathrm{~m})$, and $5(\mathrm{n}))$. To avoid synaptic degeneration due to the increased $\mathrm{A} \beta$ peptide after the loss of Pin1 activity [11], we used cultured cortical neurons from $\beta$-amyloid precursor protein $(\mathrm{APP})^{-/-}$mice to repeat these experiments. The inhibitor of Pinl and the Pinl shRNA can also decrease the levels of Shank3 proteins in neurons of $\mathrm{APP}^{-/-}$mice in vitro (data not shown). These results suggest the role of loss of Pin1 activity in reducing levels of Shank3 protein, in addition to direct $\mathrm{A} \beta$ peptide toxicity in cultured neurons.

2.5. Inhibition of Pin1 Activity Blocks NMDA ReceptorMediated Turnover of Shank3 and PSD95 Proteins and Increases NMDA Receptor- and $A \beta$ Oligomer-Mediated Degradation of Shank3 and PSD95 Proteins. The activity of synaptic NMDA receptors regulates the dynamics of proteins in PSD including Shank3 and PSD 95 protein $[19,35]$. Because the synapses of cortical neurons are functional at $12 \mathrm{DIV}$ and mature at $21 \mathrm{DIV}$ [36] and Pinl protein is already colocalized with NR1 and Shank3 proteins at dendritic spine at 15 DIV (data not shown), to detect how the loss of Pin1 activity affects levels of Shank and PSD95 proteins in neurons, here we used cortical neurons at $15 \mathrm{DIV}$ to observe NMDA receptor-mediated turnover of Shank3 and PSD95 proteins after the loss of Pinl activity. Memantine, a noncompetitive antagonist of NMDA receptors, has been used clinically in the treatment of $\mathrm{AD}$ to block neuronal oxidative stress [7]. In this test, we selected memantine and another selective competitive antagonist of NMDA receptor AP-5 to block NMDA receptor and observe the effects of Pin1 on levels of Shank3 and PSD95 proteins induced by NMDA at $0.1 \mu \mathrm{M}$ and $10 \mu \mathrm{M}$. According to several rodent studies and human clinical trials, at $10 \mu \mathrm{M}$ memantine exerts its effect at NMDA receptors [37-39] in addition to other receptors. We selected 0.5 and $5 \mu \mathrm{M}$ concentrations of memantine for this test. After memantine, NMDA, PiB, and oligomers of $\mathrm{A} \beta$ were added to cultured neurons for $24 \mathrm{~h}$ (Figure 6), neurons were then collected, and levels of Shank3 and PSD95 proteins were detected by Western blot. $5 \mu \mathrm{M}$ memantine significantly decreased levels of Shank3 and PSD95 proteins. $50 \mathrm{nM}$ (data not shown) and $100 \mathrm{nM}$ NMDA significantly increased the levels of Shank3 and PSD95 proteins; $5 \mu \mathrm{M}$ memantine (Figure 6) and $0.5 \mu \mathrm{M}$ AP-5, a selective antagonist of NMDA receptor (data not shown), blocked the increase of Shank3 and PSD95 proteins in neurons induced by $100 \mathrm{nM}$ NMDA (Figure 6). These results suggest the ability of $50 \mathrm{nM}$ and $100 \mathrm{nM}$ NMDA to induce an increase in Shank3 and PSD95 proteins and to protect synaptic function [36, 40, 41]. After the loss of Pinl activity in the presence of $\mathrm{PiB}$, the NMDA receptor-mediated increase of Shank3 and PSD95 proteins was significantly blocked (Figure 6). Meanwhile, we found that $10 \mu \mathrm{M}$ NMDA or $0.5 \mu \mathrm{M}$ PiB individually did not change the level of Shank3 protein; however when both were incubated with cultured neurons together, levels of Shank3 protein were significantly reduced. $0.5 \mu \mathrm{M}$ PiB also increased the reduction of Shank3 and PSD95 proteins induced by oligomers of $A \beta$ (Figure 6). These findings indicate that the loss of Pinl activity could block NMDA receptor-mediated turnover of Shank3 and PSD95 proteins and increase NMDA receptor- and $\mathrm{A} \beta$ oligomer-mediated degradation of Shank3 and PSD95 proteins, contributing to synaptic loss in $\mathrm{AD}$ development.

\section{Discussion}

Pin1 protein regulates the function of mitotic phosphoproteins and determines cell-cycle progression [9]. The loss of Pinl is a common pathological cause linked to the production of $\mathrm{A} \beta$ and hyperphosphorylated Tau in $\mathrm{AD}[10,11,42]$. Here we identified and showed the association of Pinl with Shank proteins at dendritic rafts and the PSD, in which both fractions are associated with NR1; this finding suggests Pinl may regulate signal transduction at dendritic rafts and signal processing at the PSD. The loss of Pinl activity alters the modification of ubiquitin in PSD proteins and leads to the loss of Shank3 protein. As a result, Pin1 loss may make aberrant synapses more susceptible to the toxic effects of molecules such as oligomers of $A \beta$ and glutamate, thereby inhibiting NMDA receptor-mediated turnover of Shank protein and synaptic generation, and exaggerating NMDA receptor-mediated synaptic degeneration. Pinl could play a pathological role in synaptic dysfunction in addition 


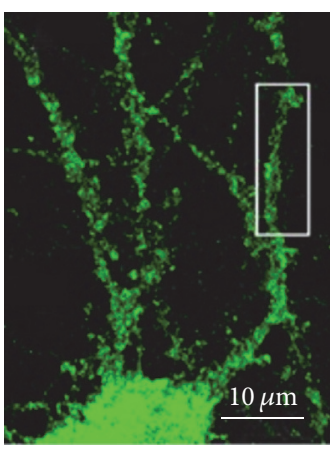

(a)

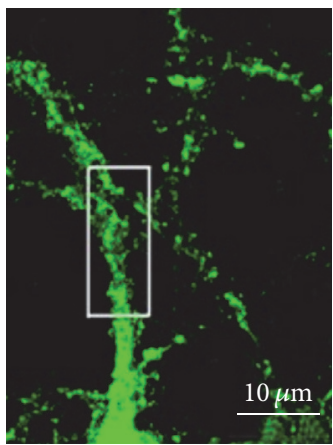

(g)

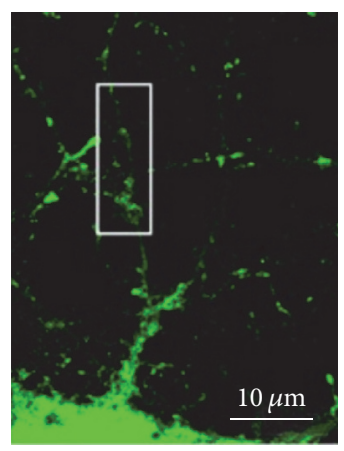

(b)

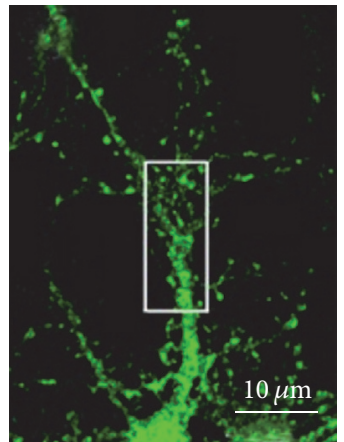

(h)

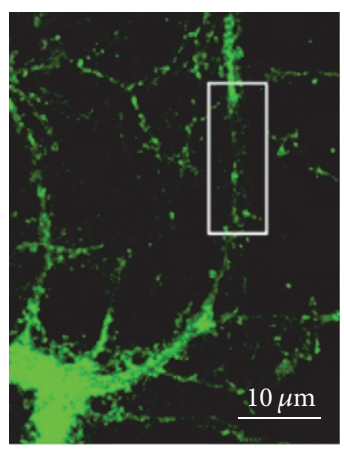

(c)

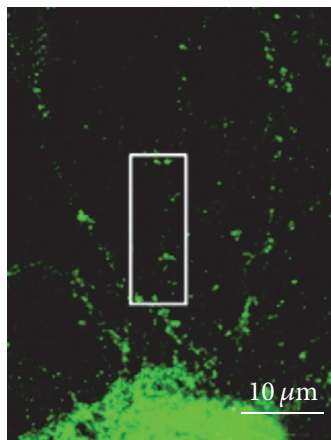

(i)

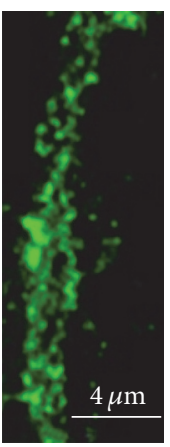

(d)

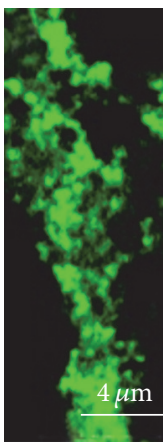

(j)

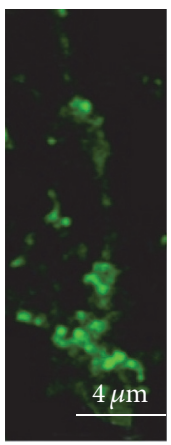

(e)

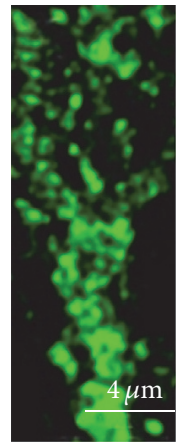

(k)

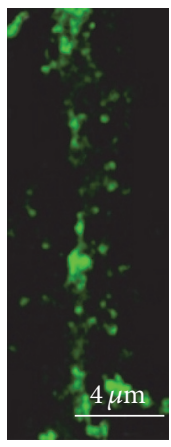

(f)

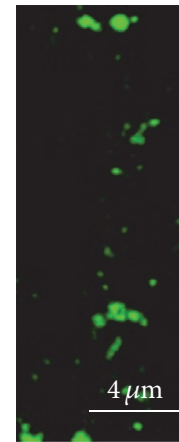

(l)
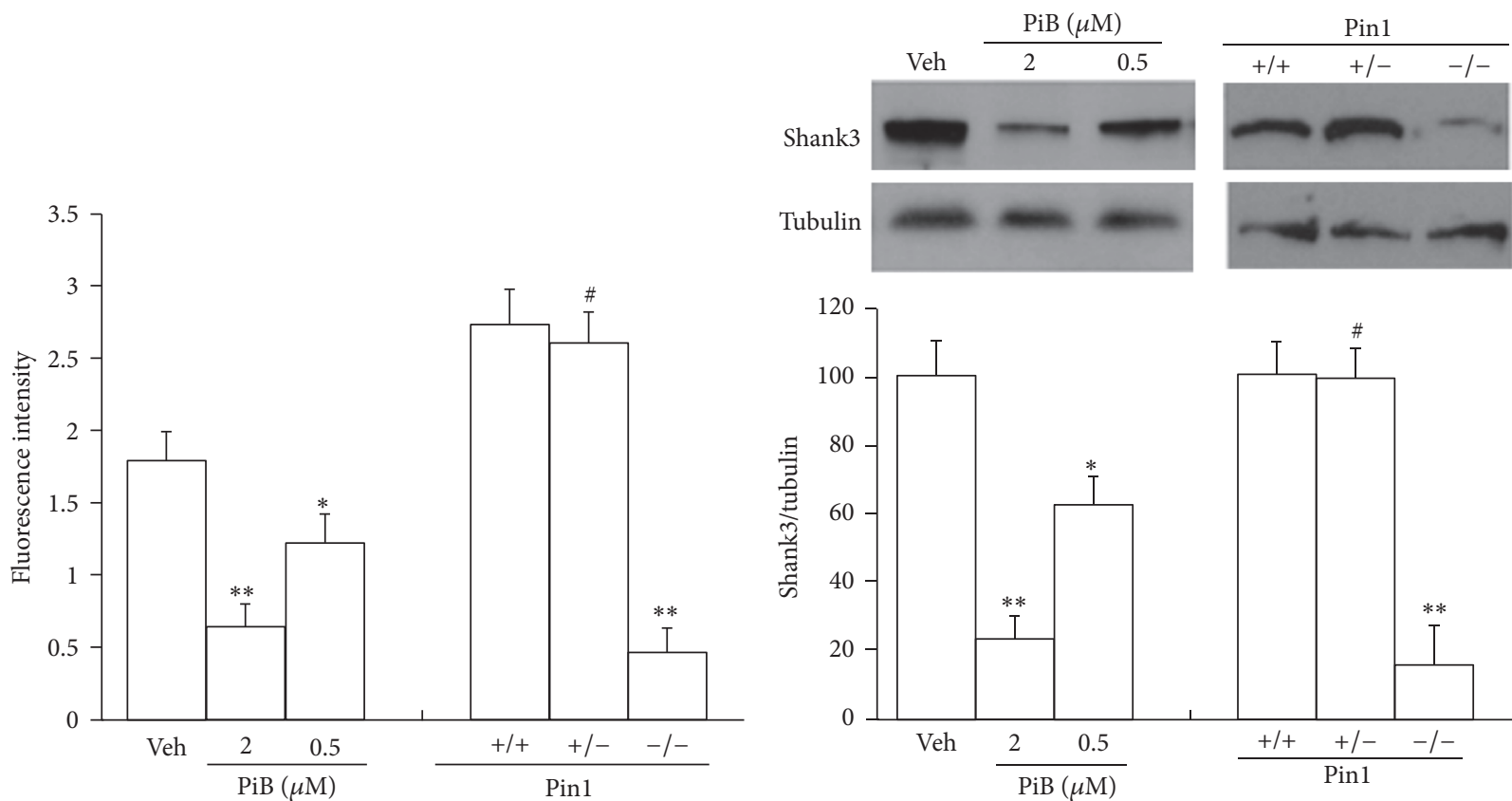

(m)

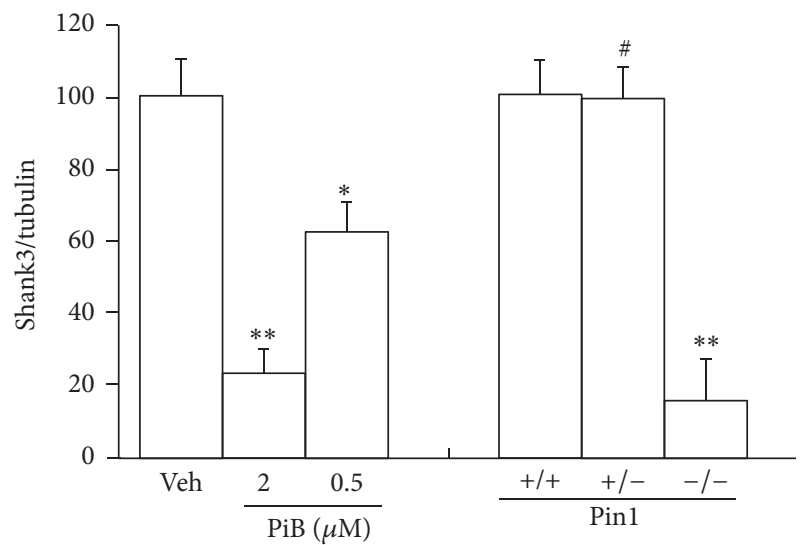

(n)

FIGURE 5: Blocking of Pinl activity leads to degradation of Shank3 proteins in PSD. Cultured cortical neurons at 21 DIV were prepared on coverslips for immunofluorescence detection and in $10 \mathrm{~cm}$ dishes for immunoblot assay. Panels (a)-(f) showed the cultured cortical neurons of C57/BL6 mice at $21 \mathrm{DIV}$ treated with vehicle ( $\mathrm{a}$ and d), $2 \mu \mathrm{M} \mathrm{PiB}$ (b and e), or $0.5 \mu \mathrm{M} \mathrm{PiB} \mathrm{(c} \mathrm{and} \mathrm{f)} \mathrm{for} 24 \mathrm{~h}$; panels (d), (e), and (f) were the high-magnification images of selected fields. Panels $(\mathrm{g})-(\mathrm{l})$ showed the cultured cortical neurons of Pinl ${ }^{+/+}(\mathrm{g}$ and $\mathrm{j}), \mathrm{Pinl}^{+/-}(\mathrm{h}$ and $\mathrm{k}$ ), and $\mathrm{Pin}^{-1-}$ (i and $\mathrm{l}$ ) mice at $21 \mathrm{DIV}$; panels $(\mathrm{j}),(\mathrm{k})$, and (l) were the high-magnification images of selected fields. These neurons on coverslips were fixed, permeabilized, and labeled by Shank3 antibody for immunofluorescence detection by immunocytochemistry. (m) Immunofluorescence intensity demonstrated a large $\mathrm{PiB}$-induced decrease in Shank3 proteins from seven independent experiments $(\sim 90$ neurons for each experimental condition, $\left.{ }^{* *} p<0.01 ;{ }^{*} p<0.05\right)$. (n) Western blots showed significant decrease in the levels of Shank3 proteins in PiB-treated or in $\mathrm{Pinl}^{-/-}$neurons compared with vehicle-treated or Pinl ${ }^{+/+}$neuron extracts, respectively $(n=7$ dishes for each experimental condition, $\left.{ }^{* *} p<0.01 ;{ }^{*} p<0.05 ;{ }^{*} p>0.05\right)$. 


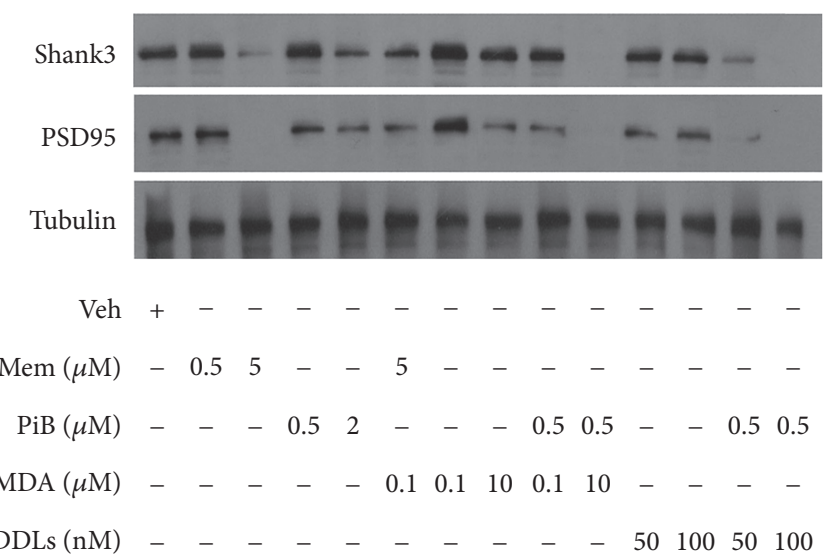

(a)

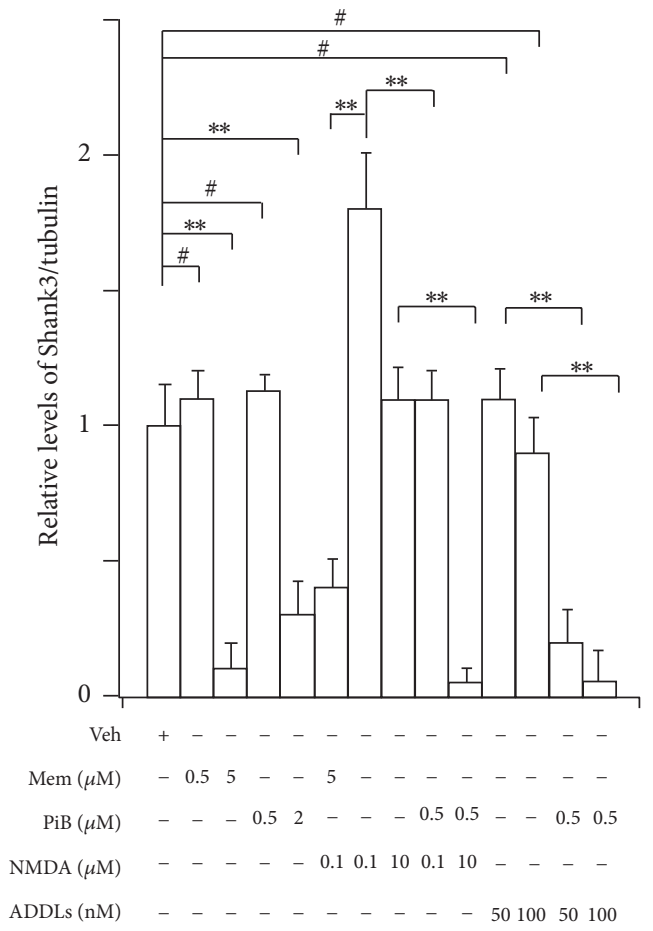

(b)

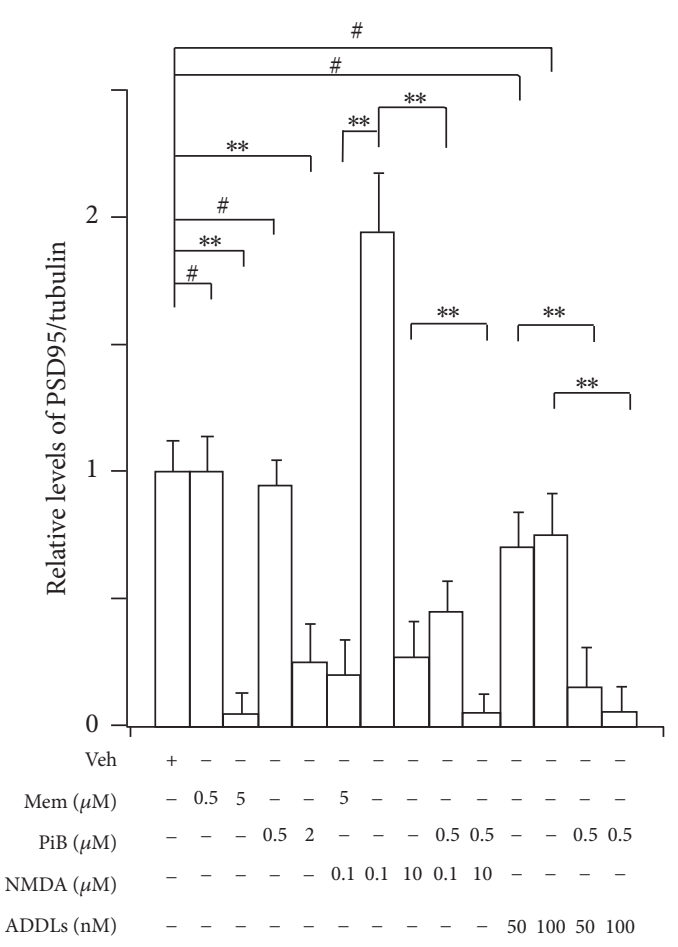

(c)

FIGURE 6: Blocking of Pinl activity blocks NMDA receptor-mediated turnover of Skank3 and increases degradation of Shank3 and PSD95 induced by oligomers of $\mathrm{A} \beta$ and NMDA in cultured neurons. Cortical neurons at 15 DIV were incubated with memantine, NMDA, PiB, and oligomers of $\mathrm{A} \beta$ for $24 \mathrm{~h}$. (a) Representative Western blot. (b and c) Results from densitometric imaging of these tests. Memantine $10 \mu \mathrm{M}$ significantly decreased levels of Shank3 and PSD95 proteins. NMDA $100 \mathrm{nM}$ significantly increased levels of these proteins, and $10 \mu \mathrm{M}$ memantine significantly inhibited the increase of Shank 3 induced by $100 \mathrm{nM}$ NMDA. When $10 \mu \mathrm{M}$ NMDA and $0.5 \mu \mathrm{M}$ PiB were incubated with neuron together, these proteins were significantly decreased. The same results were observed between PiB and oligomers of $\mathrm{A} \beta$ from seven independent experiments $\left(n=7\right.$ dishes for each experimental condition, $\left.{ }^{* *} p<0.001,{ }^{*} p>0.05\right)$.

to the formation of misfolded proteins in preclinical stages of $\mathrm{AD}$.

With aging, the activity of Pinl protein may be lost by oxidation in mild cognitive impairment $[8,43]$, which could lead to the formation of $\mathrm{A} \beta$ plaques and hyperphosphorylated Tau in preclinical stages of $\mathrm{AD}$ [10-12]. We observed that the levels of Pinl proteins are significantly lost in the synaptic fractions of $\mathrm{AD}$ brain cortical tissues (Figure 3), in addition to the loss of Pinl protein in total AD brain tissues [10]. In vitro, the loss of Pinl activity increases the modification of ubiquitination in PSD proteins (Figure 4). Modification of synaptic proteins mediates the protein-protein interactions which are required for structural plasticity of excitatory synapses. The loss of Pinl activity may be one of the earliest events leading to the pathological modification of synaptic proteins in preclinical $\mathrm{AD}$ (Figure 4) [42, 43].

Synaptic NMDA receptors protect synaptic function and stimulate synaptic generation to maintain homeostasis 
$[36,40]$ (Figure 6). Pinl protein is found in dendritic spines and regulates the synthesis of PSD 95 [30]. Here we found that Pinl proteins associate with dendritic rafts and the PSD fractions containing NMDA receptors and Shank3 proteins (Figure 1), which suggests that Pin1 may regulate signal transduction at dendritic rafts and may influence the function of Shank3 proteins and other proteins within dendritic rafts and the PSD. The normal level of glutamate in brains is $1-4 \mu \mathrm{M}$ [44]. The baseline concentration of extracellular glutamate is also reported to be near $25 \mathrm{nM}$ [45]. We selected various concentrations of NMDA to regulate the structural changes in the PSD. Shank proteins have the capability to turn over within minutes [35], organize other scaffolding proteins in addition to glutamate receptors, and induce spine formation [41]. Conversely, the loss of Shank3 protein can lead to aberrant structure of the PSD and loss of NMDA receptors [27]. In our results, $50 \mathrm{nM}$ (data not shown) and $100 \mathrm{nM}$ NMDA increased Shank3 protein levels (Figure 6). Under these conditions, NMDA may protect synapses and increase synaptic formation $[36,40]$. On the other hand, memantine and AP-5 blocked the increase of Shank3 proteins induced by NMDA at $100 \mathrm{nM}$. PiB, the inhibitor of Pinl, also clearly blocked elevations in Shank3 proteins induced by NMDA at $100 \mathrm{nM}$, which implicates the blocking of Pinl activity in inhibiting the synthesis of Shank3 induced by NMDA receptor. This confirms that Pinl may control protein synthesis in dendritic spines [30]. Interestingly, we also found that the inhibitor of Pinl could increase NMDA receptor-mediated excitotoxicity, leading to the degradation of Shank3 proteins in cultured neurons (Figure 6), which suggests that the loss of Pinl activity can increase NMDA receptor-mediated excitotoxicity in dendritic spines. To avoid the effects of increased $\mathrm{A} \beta$ peptides on the synapse after the loss of Pinl activity, we used cultured cortical neurons of $\mathrm{APP}^{-/-}$mice and found that $\mathrm{PiB}$ or Pinl shRNA was also capable of inducing Shank3 loss. These results suggest that Pinl may play a role in the NMDA receptor-mediated functional and structural plasticity of the PSD, and the loss of Pinl activity may block normal NMDA receptor-mediated synaptic formation thereby increasing the neuron's susceptibility to oligomers of $A \beta$ or other toxic events such as excitation (Figure 6). During this pathological process, the accumulation of modifications at the excitatory synapse may lead to an irreversible synaptic dysfunction and aberration of synaptic structure that cannot be normalized by synaptic NMDA receptors $[36,40]$, ultimately accelerating synaptic loss.

The PSD is a multiprotein complex organized by Shank proteins [23,24]. Mutations in this set of proteins are involved in over 133 genetic neurological diseases [24] including Shank-relevant diseases [27]. The loss of Pinl activity could affect conformational and functional changes in PSD proteins in $\mathrm{AD}$ and in other neurological diseases. Pinl activity often translates to a fate-determining ubiquitination switch, and Pinl may likewise affect the degree of ubiquitination in the degradation of PSD proteins (Figure 4) including PSD95, GKAP, Shank, and other proteins involved in the disruption of the PSD in AD $[21,28,46,47]$. Shank3 and other scaffolding proteins, PSD95 and PSD93, undergo proline-directed phosphorylation and share a similar phosphorylation motif
[48]. The alteration of Shank protein levels and modification of ubiquitin have been linked to $\mathrm{AD}[28,29]$. The loss of Pinl could affect the modification of proteins in the PSD, leading to the degradation of proteins by the UPS (Figure 4) and contributing to the aberrant structure of the PSD in AD. Proteasome activity declines with aging and in AD brains [49], and we found that loss of Pinl activity can significantly increase the ubiquitin modification and degradation of Shank3 protein in cultured neurons (Figures 4,5 , and 6 ). These results suggest that the NMDA receptormediated activity of the ubiquitin system can be altered, leading to the degradation of PSD proteins after the loss of Pinl activity in dendritic spine. In addition, Pinl could also directly bind to phosphorylated Shank3 protein and affect the levels of Shank3 protein in dendritic spine. These relevant molecular mechanisms warrant further investigation.

\section{Experimental Procedure}

4.1. Human AD and Mice Brain Tissues. Human brain tissues were obtained at autopsy from 8 patients diagnosed clinically and histopathologically with $\mathrm{AD}(80.9 \pm 2.7$ years $)$ in the postmortem period $(5.5 \pm 0.8 \mathrm{~h})$ and from 5 age-matched controls with no clinical or morphologic evidence of brain pathology $(81.4 \pm 2.0$ years $)$ in the postmortem period $(5.0 \pm 1.0 \mathrm{~h})$. The ages and PMDs of cases were not significantly different between the $\mathrm{AD}$ and control group. In this study, we focused on excitatory synapses and the potential effects of medications on glutamate receptor levels. None of our control or AD subjects were on memantine, an antagonist of NMDA receptor, or other NMDA receptor modulators. All tissues were obtained from the DUCOM Memory Disorders brain bank.

Pinl knockout mice were bred in Flavio Rizzolio's laboratory (Temple University, Philadelphia, PA). Tg2576 mice were bred in the animal facility center at Drexel University College of Medicine.

4.2. Cortical Neuron Culture and Treatment. Cortical neurons of C57/BL6 mice at E18 and Pin1 knockout mice at P0 were cultured on coverslips for immunocytochemical analysis, in $10 \mathrm{~cm}$ dishes for dendritic raft or PSD isolation or in 24well plates for Western blot, as described previously [50, 51]. To culture the neurons of Pinl ${ }^{-/-}$mice, the cortical neurons of pups at P0 from Pinl ${ }^{+/-}$mice cross-bred with Pinl ${ }^{+/-}$mice were cultured individually, and the pups were genotyped. These cultured cortical cells at various times (from 12 to 21 DIV for different tests) were treated with memantine, AP-5, NMDA, PiB, Pinl shRNA lentivirus particle, control shRNA lentivirus particle, and vehicle as indicated in the figures. $\mathrm{PiB}$, a selective Pin inhibitor $[33,34]$, was used to block the activity of Pin1. Pinl shRNA lentivirus particles were used to create Pinl knockdowns [52].

4.3. Synaptosome, Dendritic Raft, and PSD Preparation. Synaptosomes were prepared from frontal cortical tissues of human brains, from cultured neurons, or from cortical or hippocampal tissues of mice brains $[28,53]$. Dendritic rafts fractions were prepared from synaptosomes $[15,54]$. PSD fractions were prepared from synaptosomes [31]. 
4.4. Ubiquitinated-Protein Affinity Isolation. PSD fractions were isolated from cultured neurons with or without treatment of PiB, Pinl shRNA lentivirus particles, control shRNA lentivirus particles, or vehicle. Proteins from these PSD fractions at equal amounts were solubilized in TBS buffer $(10 \mathrm{mM}$ Tris- $\mathrm{HCl}, 100 \mathrm{mM} \mathrm{NaCl}$ ) with $0.1 \%$ SDS at $70^{\circ} \mathrm{C}$ for $15 \mathrm{~min}$. The ubiquitinated proteins in supernatant at $100,000 \times \mathrm{g}$ for 30 min were pulled down by ubiquitin-interacting motif affinity gel (polyubiquitin enrichment kit, Pierce Biotechnology) according to the manufacturer's instructions. These gels were washed three times by TBS buffer with $0.1 \%$ SDS. Finally, 1\% SDS Laemmli sample buffer was used to elute ubiquitinated proteins for Western blot analysis.

4.5. Oligomers of $A \beta$ (ADDLs) Preparation. Oligomers of $\mathrm{A} \beta_{1-42}$ peptide were prepared as previously described $[50,55]$.

4.6. Immunoblot. Western and dot blot analyses were based on published procedures [50]. For Western blot analysis, the samples were separated by $4 \%-20 \%$ glycine-HCl SDSpolyacrylamide gel or $16.5 \%$ Tris-tricine SDS-polyacrylamide gel electrophoresis and then transferred to nitrocellulose membrane. For dot blot analysis, the samples of dendritic rafts, PSDs, and synaptosome fractions were treated by $0.1 \%$ SDS or by Ham's F-12 medium, and proteins of these samples in equal amounts were dotted on nitrocellulose membrane. The proteins were recognized by specific antibodies and visualized with ECL. Antibodies to flotillin (rabbit), Shank3 (rabbit and goat), NR1 of NMDA receptor subunit (rabbit), PSD95 (goat), Pin1 (mouse and rabbit), calnexin (rabbit), and $\beta$-tubulin (rabbit) were from Santa Cruz Biotechnology (Santa Cruz, CA). Antibody All to oligomers of $\mathrm{A} \beta$ was from Invitrogen [56]. Antibody (rabbit) to Tau [p-231] was from Covance (Emeryville, CA). A polyubiquitin enrichment kit and antibody to ubiquitin (rabbit) were obtained from Pierce, and Alexa-conjugated secondary antibodies were from Invitrogen. Hybond ECL nitrocellulose, HRPconjugated secondary, and rainbow protein ladders were from Amersham Pharmacia Biosciences.

4.7. Coimmunoprecipitation. IP was carried out by incubation of synapse lysates of human control brain cortical tissues. Synaptosomes containing $200 \mu \mathrm{g}$ protein were resuspended in buffer A containing $50 \mathrm{mM}$ Tris ( $\mathrm{pH} 7.5$ ), $100 \mathrm{mM} \mathrm{NaCl}$, $1.5 \mathrm{mM}$ EGTA, $0.1 \%$ SDS, and 1\% Triton X-100 for 1 hour at $4^{\circ} \mathrm{C}$. The supernatant from $100,000 \mathrm{~g}$ for 30 minutes was incubated with specific antibodies plus Protein G agarose (Invitrogen) at $4^{\circ} \mathrm{C}$ overnight, followed by washing 5 times in a buffer B containing $50 \mathrm{mM}$ Tris (pH 7.5), $100 \mathrm{mM} \mathrm{NaCl}$, and $1.5 \mathrm{mM} 0.1 \%$ Triton X-100. Antibodies used for IP were rabbit polyclonal anti-Pin1 and anti-Shank3 (Santa Cruz) and rabbit IgG (Sigma-Aldrich) as negative controls. The IP was analyzed by Western blot using mouse monoclonal anti-Pin1 and goat polyclonal anti-Shank3 (Santa Cruz).

4.8. Immunocytochemistry. Treated cells were rinsed with neurobasal media and then fixed with $3.7 \%$ formaldehyde in neurobasal media ( $1: 1$ volume) for $20 \mathrm{~min}$ followed by an additional $20 \mathrm{~min}$ of undiluted fixative. Cells were rinsed extensively in PBS. Coverslips were incubated in blocking solution (10\% BSA in PBS with or without $0.1 \%$ Triton $\mathrm{X}-100$ ) for $45 \mathrm{~min}$ at room temperature. Antibodies were used against Pinl, NR1, and Shank3. Primary antibodies were diluted in blocking solution and incubated overnight at $4^{\circ} \mathrm{C}$. After rinsing with PBS with $1 \%$ BSA, coverslips were incubated with appropriate Alexa-conjugated secondary antibodies diluted in PBS plus 1\% PBS for $90 \mathrm{~min}$ at room temperature, rinsed in PBS three times, and mounted with ProLong Antifade media [51]. Quantitative analysis of the immunofluorescence intensity at dendritic arbors was performed by histogram analysis using ImageJ. Shank 3 proteins were expressed in excitatory neurons and at the PSDs of dendritic spines [23]. Cell bodies were digitally removed from images; the Shank3 proteins at dendritic arbors were analyzed. Thirty images were acquired under each experimental condition, and these tests were done in triplicate. The data were pooled for quantitative estimates of changes in Shank3 protein. Three independent experiments were performed for each test [7].

4.9. Statistical Analysis. For each experiment, two or three independent replicated experiments were performed. The densities of immunoblot were acquired with densitometric scan and quantified with ImageJ. Results were expressed as means \pm SEM. The data were analyzed with one-way analysis of variance. Statistical significance was determined at $p<$ 0.05 .

\section{Conclusion}

Here we found Pinl proteins exist in detergent-resistant dendritic rafts and PSDs at the precise location of key macromolecules including NMDA, AMPA, mGlu receptors, and Shank proteins for synaptic plasticity. The loss of synaptic Pinl activity may alter the modifications of ubiquitin in PSD proteins and lead to the loss of Shank 3 proteins and formation of aberrant synapses which are more susceptible to toxic effects of molecules such as oligomers of $A \beta$ and glutamate. Toxicity thereby inhibits NMDA receptor-mediated turnover of Shank3 and PSD95 and exaggerates NMDA receptormediated loss of Shank3 and PSD95 proteins. These multiple factors could work together to exacerbate synaptic dysfunction in preclinical AD. The loss of Pinl activity could play an integral role in the pathogenesis of synaptic dysfunction contributing to the onset of clinical AD.

\section{Abbreviations}

AD: Alzheimer's disease

Pinl: Peptidyl-prolyl cis-trans isomerase

NIMA-interacting 1

PSD: Postsynaptic density

NR1: N-Methyl-D-aspartate (NMDA) receptor 1

UPS: Ubiquitin proteasome system

$\mathrm{A} \beta$ : $\quad \beta$-Amyloid peptides

ADDLs: $A \beta$ oligomeric ligands 
PiB: Benzo[lmn][3,8]phenanthroline-2,7diacetic acid,

1,3,6,8-tetrahydro-1,3,6,8-tetraoxo-, 2,7-diethyl ester, Pin1 selective inhibitor

MG-132: Z-Leu-Leu-Leu-al, proteasome inhibitor.

\section{Competing Interests}

The authors have reported no conflict of interests.

\section{Acknowledgments}

This work was financially supported by the Priority Academic Program Development (PAPD) fund of the Jiangsu Higher Education Institution and NIH Grant R21AG031388 (Dr. Gong). The authors would like to thank Robert Schwartzman and Guillermo M. Alexander for their kind help with the experiments. They also would like to thank Diana Winters for her kind help with reading the manuscript.

\section{References}

[1] C. Haass and D. J. Selkoe, "Soluble protein oligomers in neurodegeneration: lessons from the Alzheimer's amyloid $\beta$-peptide," Nature Reviews Molecular Cell Biology, vol. 8, no. 2, pp. 101-112, 2007.

[2] H. Braak and E. Braak, "Diagnostic criteria for neuropathologic assessment of Alzheimer's disease," Neurobiology of Aging, vol. 18, no. 4, pp. S85-S88, 1997.

[3] E. Grober, D. Dickson, M. J. Sliwinski et al., "Memory and mental status correlates of modified Braak staging," Neurobiology of Aging, vol. 20, no. 6, pp. 573-579, 1999.

[4] T. E. Golde, "Alzheimer disease therapy: can the amyloid cascade be halted?" Journal of Clinical Investigation, vol. 111, no. 1, pp. 11-18, 2003.

[5] D. J. Selkoe, "Alzheimer's disease is a synaptic failure," Science, vol. 298, no. 5594, pp. 789-791, 2002.

[6] D. J. Selkoe, "Preventing alzheimer's disease," Science, vol. 337, no. 6101, pp. 1488-1492, 2012.

[7] F. G. De Felice, P. T. Velasco, M. P. Lambert et al., "A $\beta$ oligomers induce neuronal oxidative stress through an N-methyl-Daspartate receptor-dependent mechanism that is blocked by the Alzheimer drug memantine," Journal of Biological Chemistry, vol. 282, no. 15, pp. 11590-11601, 2007.

[8] R. Sultana, D. Boyd-Kimball, H. F. Poon et al., "Oxidative modification and down-regulation of Pinl in Alzheimer's disease hippocampus: a redox proteomics analysis," Neurobiology of Aging, vol. 27, no. 7, pp. 918-925, 2006.

[9] E. S. Yeh and A. R. Means, "PIN1, the cell cycle and cancer," Nature Reviews Cancer, vol. 7, no. 5, pp. 381-388, 2007.

[10] P.-J. Lu, G. Wulf, X. Z. Zhou, P. Davies, and K. P. Lu, “The prolyl isomerase Pinl restores the function of Alzheimer-associated phosphorylated tau protein," Nature, vol. 399, no. 6738, pp. 784788, 1999.

[11] L. Pastorino, A. Sun, P. J. Lu et al., "The prolyl isomerase Pin1 regulates amyloid precursor protein processing and amyloidbeta production," Nature, vol. 440, pp. 528-534, 2006.

[12] A. Maruszak, K. Safranow, K. Gustaw et al., "PIN1 gene variants in Alzheimer's disease," BMC Medical Genetics, vol. 10, article $115,2009$.
[13] K. Nakamura, I. Kosugi, D. Y. Lee et al., "Prolyl isomerase pinl regulates neuronal differentiation via $\beta$-catenin," Molecular and Cellular Biology, vol. 32, no. 15, pp. 2966-2978, 2012.

[14] Y.-C. Liou, A. Sun, A. Ryo et al., "Role of the prolyl isomerase Pin1 in protecting against age-dependent neurodegeneration," Nature, vol. 424, no. 6948, pp. 556-561, 2003.

[15] T. Kawarabayashi, M. Shoji, L. H. Younkin et al., "Dimeric amyloid $\beta$ protein rapidly accumulates in lipid rafts followed by apolipoprotein $\mathrm{E}$ and phosphorylated tau accumulation in the Tg2576 mouse model of Alzheimer's disease," Journal of Neuroscience, vol. 24, no. 15, pp. 3801-3809, 2004.

[16] R. M. Koffie, M. Meyer-Luehmann, T. Hashimoto et al., "Oligomeric amyloid $\beta$ associates with postsynaptic densities and correlates with excitatory synapse loss near senile plaques," Proceedings of the National Academy of Sciences of the United States of America, vol. 106, no. 10, pp. 4012-4017, 2009.

[17] M. P. Coba, A. J. Pocklington, M. O. Collins et al., "Neurotransmitters drive combinatorial multistate postsynaptic density networks," Science Signaling, vol. 2, no. 68, p. ra19, 2009.

[18] J. C. Trinidad, C. G. Specht, A. Thalhammer, R. Schoepfer, and A. L. Burlingame, "Comprehensive identification of phosphorylation sites in postsynaptic density preparations," Molecular and Cellular Proteomics, vol. 5, no. 5, pp. 914-922, 2006.

[19] S. Okabe, H.-D. Kim, A. Miwa, T. Kuriu, and H. Okado, "Continual remodeling of postsynaptic density and its regulation by synaptic activity," Nature Neuroscience, vol. 2, no. 9, pp. 804-811, 1999.

[20] G. Wulf, G. Finn, F. Suizu, and K. P. Lu, "Phosphorylationspecific prolyl isomerization: is there an underlying theme?" Nature Cell Biology, vol. 7, no. 5, pp. 435-441, 2005.

[21] M. D. Ehlers, "Activity level controls postsynaptic composition and signaling via the ubiquitin-proteasome system," Nature Neuroscience, vol. 6, no. 3, pp. 231-242, 2003.

[22] D. Siepe and S. Jentsch, "Prolyl isomerase Pin1 acts as a switch to control the degree of substrate ubiquitylation," Nature Cell Biology, vol. 11, no. 8, pp. 967-972, 2009.

[23] T. M. Boeckers, "The postsynaptic density," Cell and Tissue Research, vol. 326, no. 2, pp. 409-422, 2006.

[24] Á. Bayés, L. N. Van De Lagemaat, M. O. Collins et al., "Characterization of the proteome, diseases and evolution of the human postsynaptic density," Nature Neuroscience, vol. 14, pp. 19-21, 2011.

[25] C. M. Durand, C. Betancur, T. M. Boeckers et al., "Mutations in the gene encoding the synaptic scaffolding protein SHANK3 are associated with autism spectrum disorders," Nature Genetics, vol. 39, no. 1, pp. 25-27, 2007.

[26] M. A. Bangash, J. M. Park, T. Melnikova et al., "Enhanced polyubiquitination of shank3 and NMDA receptor in a mouse model of autism," Cell, vol. 145, no. 5, pp. 758-772, 2011.

[27] J. Peça, C. Feliciano, J. T. Ting et al., "Shank3 mutant mice display autistic-like behaviours and striatal dysfunction," Nature, vol. 472, no. 7344, pp. 437-442, 2011.

[28] Y. Gong, C. F. Lippa, J. Zhu, Q. Lin, and A. L. Rosso, "Disruption of glutamate receptors at Shank-postsynaptic platform in Alzheimer's disease," Brain Research, vol. 1292, pp. 191-198, 2009.

[29] E. Pham, L. Crews, K. Ubhi et al., "Progressive accumulation of amyloid- $\beta$ oligomers in Alzheimer's disease and in amyloid precursor protein transgenic mice is accompanied by selective alterations in synaptic scaffold proteins," FEBS Journal, vol. 277, no. 14, pp. 3051-3067, 2010. 
[30] P. R. Westmark, C. J. Westmark, S. Wang et al., "Pinl and PKM sequentially control dendritic protein synthesis," Science Signaling, vol. 3, no. 112, article ral8, 2010.

[31] K.-O. Cho, C. A. Hunt, and M. B. Kennedy, "The rat brain postsynaptic density fraction contains a homolog of the drosophila discs-large tumor suppressor protein," Neuron, vol. 9, no. 5, pp. 929-942, 1992.

[32] D. E. Harrison, R. Strong, Z. D. Sharp et al., "Rapamycin fed late in life extends lifespan in genetically heterogeneous mice," Nature, vol. 460, no. 7253, pp. 392-395, 2009.

[33] T. Uchida, M. Takamiya, M. Takahashi et al., "Pin1 and Par14 peptidyl prolyl isomerase inhibitors block cell proliferation," Chemistry and Biology, vol. 10, no. 1, pp. 15-24, 2003.

[34] M. Moretto-Zita, H. Jin, Z. Shen, T. Zhao, S. P. Briggs, and Y. Xu, "Phosphorylation stabilizes Nanog by promoting its interaction with Pin1," Proceedings of the National Academy of Sciences of the United States of America, vol. 107, no. 30, pp. 13312-13317, 2010.

[35] T. Bresler, M. Shapira, T. Boeckers et al., "Postsynaptic density assembly is fundamentally different from presynaptic active zone assembly," Journal of Neuroscience, vol. 24, no. 6, pp. 15071520, 2004.

[36] F. X. Soriano, S. Papadia, F. Hofmann, N. R. Hardingham, H. Bading, and G. E. Hardingham, "Preconditioning doses of NMDA promote neuroprotection by enhancing neuronal excitability," Journal of Neuroscience, vol. 26, no. 17, pp. 45094518, 2006.

[37] H.-S. V. Chen and S. A. Lipton, "Mechanism of memantine block of NMDA-activated channels in rat retinal ganglion cells: uncompetitive antagonism," Journal of Physiology, vol. 499, no. 1, pp. 27-46, 1997.

[38] S. A. Lipton, "Paradigm shift in neuroprotection by NMDA receptor blockade: memantine and beyond," Nature Reviews Drug Discovery, vol. 5, no. 2, pp. 160-170, 2006.

[39] P. Xia, H.-S. V. Chen, D. Zhang, and S. A. Lipton, "Memantine preferentially blocks extrasynaptic over synaptic NMDA receptor currents in hippocampal autapses," Journal of Neuroscience, vol. 30, no. 33, pp. 11246-11250, 2010.

[40] G. E. Hardingham and H. Bading, "Synaptic versus extrasynaptic NMDA receptor signalling: implications for neurodegenerative disorders," Nature Reviews Neuroscience, vol. 11, no. 10, pp. 682-696, 2010.

[41] G. Roussignol, F. Ango, S. Romorini et al., "Shank expression is sufficient to induce functional dendritic spine synapses in aspiny neurons," Journal of Neuroscience, vol. 25, no. 14, pp. 3560-3570, 2005.

[42] K. P. Lu and X. Z. Zhou, "The prolyl isomerase PIN1: a pivotal new twist in phosphorylation signalling and disease," Nature Reviews Molecular Cell Biology, vol. 8, no. 11, pp. 904-916, 2007.

[43] D. A. Butterfield, H. M. Abdul, W. Opii et al., "Pin1 in Alzheimer's disease," Journal of Neurochemistry, vol. 98, no. 6, pp. 1697-1706, 2006.

[44] G. Nyitrai, K. A. Kékesi, and G. Juhász, "Extracellular level of GABA and Glu: in vivo microdialysis-HPLC measurements," Current Topics in Medicinal Chemistry, vol. 6, no. 10, pp. 935940, 2006.

[45] M. A. Herman and C. E. Jahr, "Extracellular glutamate concentration in hippocampal slice," Journal of Neuroscience, vol. 27, no. 36, pp. 9736-9741, 2007.

[46] M. Colledge, E. M. Snyder, R. A. Crozier et al., "Ubiquitination regulates PSD-95 degradation and AMPA receptor surface expression," Neuron, vol. 40, no. 3, pp. 595-607, 2003.
[47] Y. Gong and C. F. Lippa, "Disruption of the postsynaptic density in Alzheimer's disease and other neurodegenerative dementias," American Journal of Alzheimer's Disease and other Dementias, vol. 25, no. 7, pp. 547-555, 2010.

[48] H. Jaffe, L. Vinade, and A. Dosemeci, "Identification of novel phosphorylation sites on postsynaptic density proteins," Biochemical and Biophysical Research Communications, vol. 321, no. 1, pp. 210-218, 2004.

[49] S. Oh, H. S. Hong, E. Hwang et al., "Amyloid peptide attenuates the proteasome activity in neuronal cells," Mechanisms of Ageing and Development, vol. 126, no. 12, pp. 1292-1299, 2005.

[50] Y. Gong, L. Chang, K. L. Viola et al., "Alzheimer's diseaseaffected brain: presence of oligomeric $\mathrm{A} \beta$ ligands (ADDLs) suggests a molecular basis for reversible memory loss," Proceedings of the National Academy of Sciences of the United States of America, vol. 100, no. 18, pp. 10417-10422, 2003.

[51] P. N. Lacor, M. C. Buniel, P. W. Furlow et al., "A $\beta$ oligomerinduced aberrations in synapse composition, shape, and density provide a molecular basis for loss of connectivity in Alzheimer's disease," Journal of Neuroscience, vol. 27, no. 4, pp. 796-807, 2007.

[52] T. Liu, Y. Huang, R. I. Likhotvorik, L. Keshvara, and D. G. Hoyt, "Protein never in mitosis gene A interacting-1 (PIN1) regulates degradation of inducible nitric oxide synthase in endothelial cells," American Journal of Physiology -Cell Physiology, vol. 295, no. 3, pp. C819-C827, 2008.

[53] P. R. Dodd, J. A. Hardy, A. E. Oakley, J. A. Edwardson, E. K. Perry, and J.-P. Delaunoy, "A rapid method for preparing synaptosomes: comparison, with alternative procedures," Brain Research, vol. 226, no. 1-2, pp. 107-118, 1981.

[54] T. Suzuki, J. Zhang, S. Miyazawa, Q. Liu, M. R. Farzan, and W.-D. Yao, "Association of membrane rafts and postsynaptic density: proteomics, biochemical, and ultrastructural analyses," Journal of Neurochemistry, vol. 119, no. 1, pp. 64-77, 2011.

[55] M. P. Lambert, A. K. Barlow, B. A. Chromy et al., "Diffusible, nonfibrillar ligands derived from $\mathrm{A} \beta_{1-42}$ are potent central nervous system neurotoxins," Proceedings of the National Academy of Sciences of the United States of America, vol. 95, no. 11, pp. 6448-6453, 1998.

[56] R. Kayed, E. Head, J. L. Thompson et al., "Common structure of soluble amyloid oligomers implies common mechanism of pathogenesis," Science, vol. 300, no. 5618, pp. 486-489, 2003. 

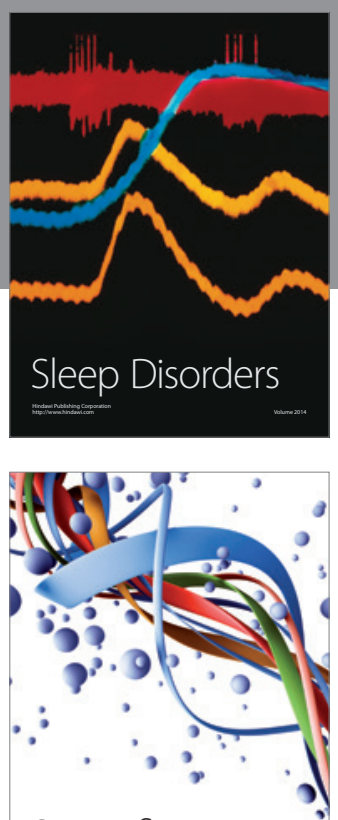

Scientifica
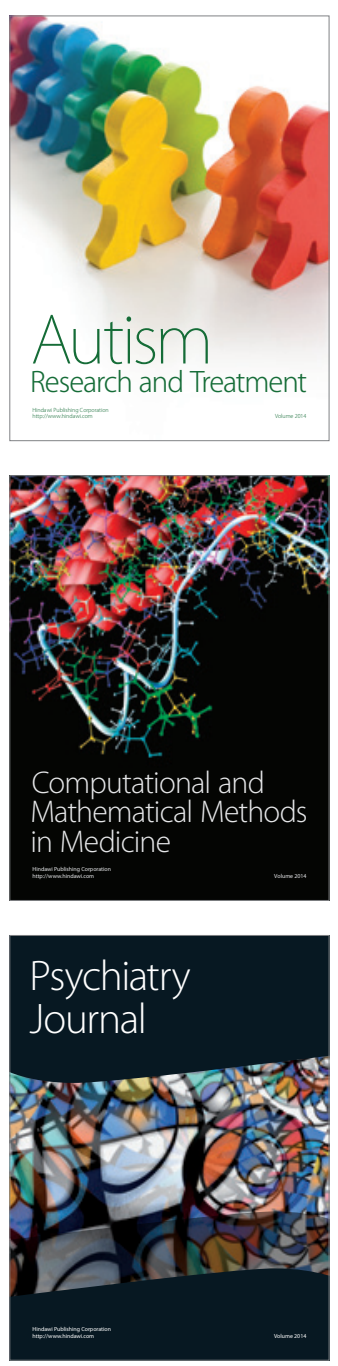
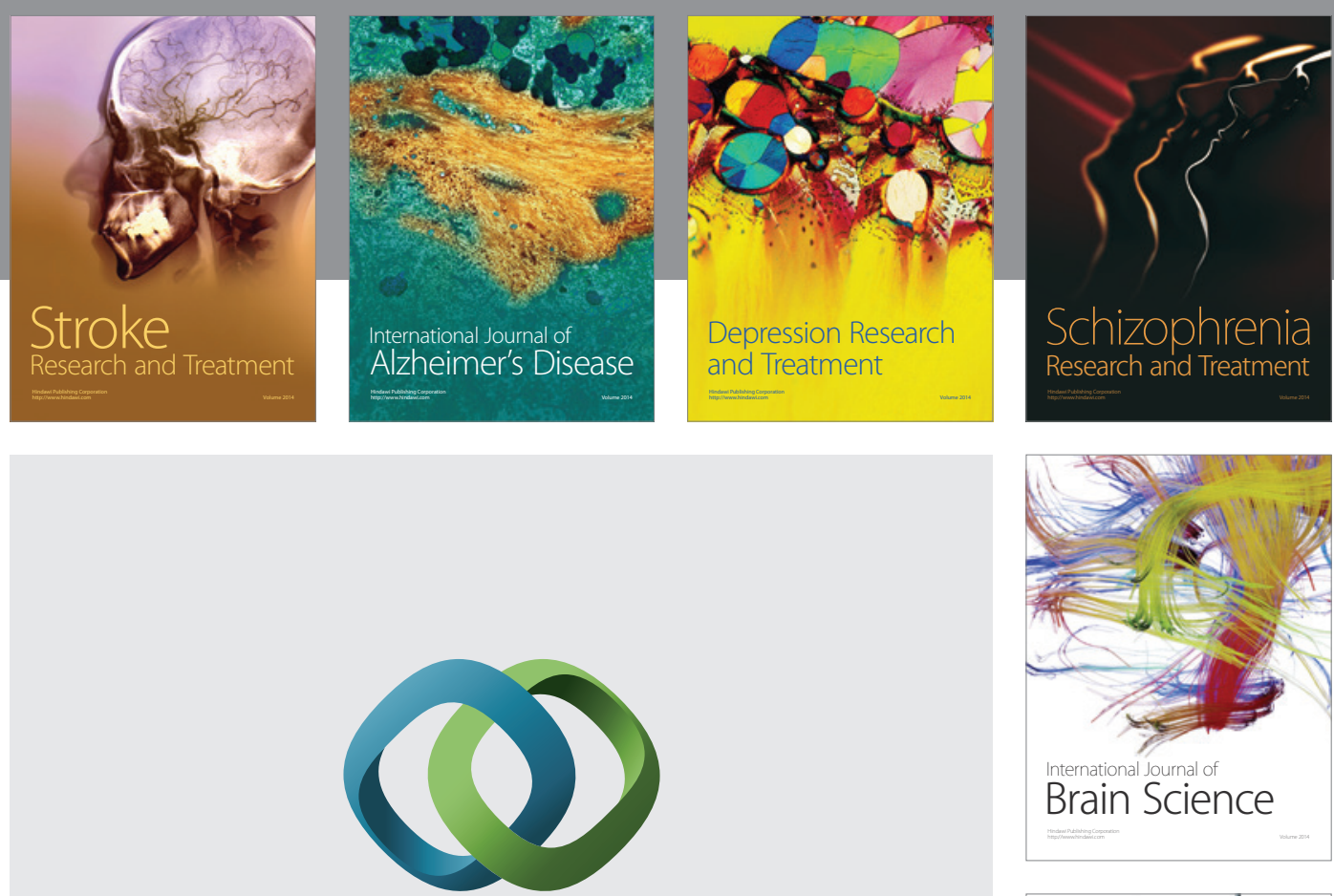

\section{Hindawi}

Submit your manuscripts at

https://www.hindawi.com
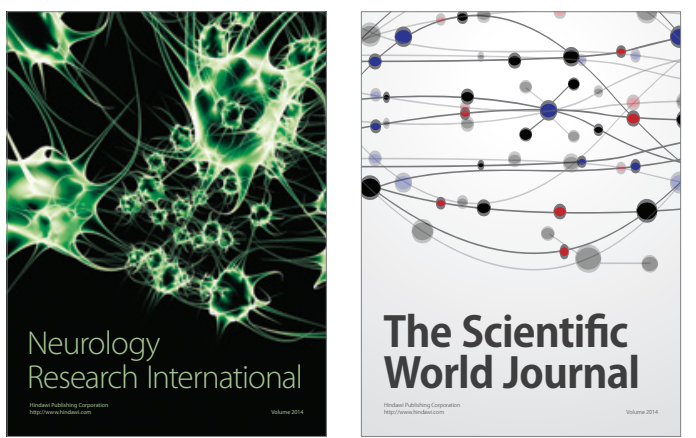

The Scientific World Journal

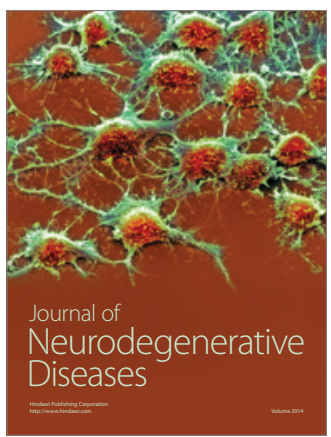

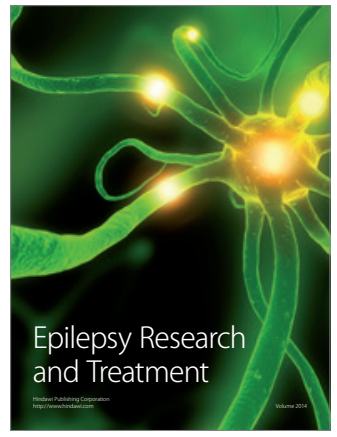

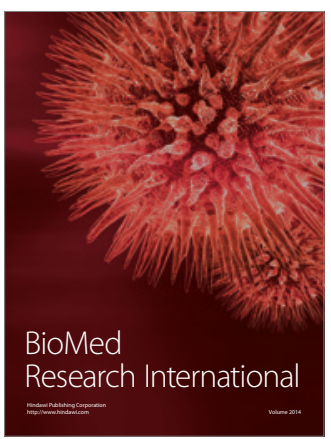

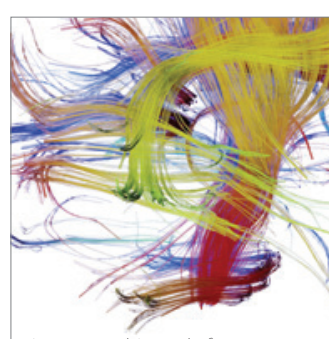

Brain Science

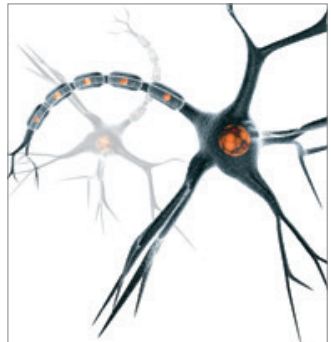

Neural Plasticity
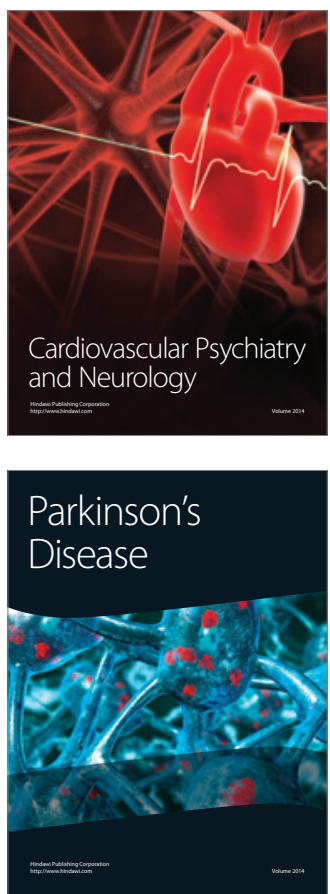